\title{
Profiling Tree Nurseries in Northern Mindanao, the Philippines
}

\author{
Don Immanuel Edralin and Agustin Mercado Jr
}

\author{
World Agroforestry Centre (ICRAF-Mindanao), MOSCAT Campus, Claveria, \\ Misamis Oriental, the Philippines
}

\begin{abstract}
Forestry nurseries play an important role in supporting small-scale plantations, tree farming as well as government initiated afforestation and reforestation programs. However, some major constraints have been identified in the forestry nursery sector in the Philippines, particularly in the supply of high quality planting materials. This hindrance is being investigated to formulate intervention points as part of a continuing research project on enhancing tree seedling supply via economic and policy changes, funded by the Australian Centre for International Agricultural Research (ACIAR). This paper presents baseline information regarding the profile of forestry nurseries in the Northern Mindanao region of the Philippines through personal interviews of operators of private, communal and government nurseries. Most nurseries in all three nursery types are operating on a small scale and are strategically situated based on the purpose of their existence. Private nurseries, being business-oriented, are located near main roads, as are government nurseries which distribute seedlings mostly without charge but in some cases for sale. Communal nurseries are mostly situated on farms because they cater to the seedling needs of their members and are therefore established far away from main roads. In terms of stability, private and government nurseries are stable compared to communal nurseries which rely on support organizations. When the support ceases communal nurseries also cease to operate. There is no current policy that supports the production and use of high quality seedlings. Intervention points to address these problems are seen as necessary extension efforts in promoting the use of high quality seedlings, thereby creating a strong seedling market, training operators to increase their capability to produce high quality seedlings, and promoting and supporting the forestry nursery industry, including the introduction of tree nursery certification.
\end{abstract}

Keywords: snowball sampling, nursery capacity, communal nurseries, certification

\section{INTRODUCTION}

Rapid deforestation, a shortfall of timber for the domestic market, conversion of forestland to agriculture and major land degradation resulting from extensive logging in the Philippines (Dart et al. 2001) have been closely linked with land degradation, lowland flooding, and degradation of rivers (Harrison and Herbohn 2001). Mercado 
and Piñon (2008) found that in 2003 regular sawmills, mini-sawmills and plywood plants were operating far below capacity due to timber shortage, with an annual log production of only 35,166 $\mathrm{m}^{3}$ of the 528,575 $\mathrm{m}^{3}$ demand. The Philippine Government, through the Department of Environment and Natural Resources (DENR), National Forestation Program (NFP) and the Forestry Master Plan (FMP) has underscored the importance of tree plantations as a viable alternative to the dwindling supply of wood products (Galinato 2009).

Galinato (2009) accounted a total of 95,257 ha in Northern Mindanao planted to trees on both timberland and privately owned land as a result of the NFP, the Green Philippines Program (GPP) and other government programs. Tree planting endeavours in the region have been extensive, with an estimated use of about $24 \mathrm{M}$ seedlings from tree nurseries. Tree nurseries are places where seeds and cuttings are planted and where the resulting seedlings are nurtured in preparation for field planting (Longman 2002). Nurseries, including those of smallholders, are important sources of seedlings to support the increasing demand for timber planting materials for tree domestication efforts such as smallholder tree farming and reforestation.

The potential market for timber seedlings is huge, especially for smallholder farmers because they are the source of most of the timber supplied to the $135 \mathrm{mini}$ sawmills in Northern Mindanao (Bertomeu 2003). Continuing efforts to reforest more areas in the region will demand more seedlings from tree nurseries, and are likely to lead to a lucrative tree nursery business.

This paper reports the research methods designed to improve the understanding of the forestry seedling nursery sector in Northern Mindanao (Philippines Region 10), and specifically to determine the profile of seedling nurseries, especially with regard to their purpose and scale of operation, through a survey of nursery operators. The study was conducted in the context of a research program conducted by the World Agroforestry Centre (ICRAF) and the Australian Centre for International Agricultural Research (ACIAR) on enhancing tree seedling supply via economic and policy changes in the Philippines nursery sector.

\section{RESEARCH METHOD}

Northern Mindanao is composed of five provinces, eight cities (including the highly urbanized cities of Cagayan de Oro and Iligan), and 85 municipalities. It has a total area of $14,033 \mathrm{~km}^{2}$ of which Bukidnon is the largest municipality $\left(8293.8 \mathrm{~km}^{2}\right)$ and Camiguin the smallest $\left(229.82 \mathrm{~km}^{2}\right)$. The population of the region is about $3.95 \mathrm{M}$ (NSO 2007). The land is mostly classified as forestland (60\% of land area) while the remainder is agricultural land.

Lists of nursery operators within the region were obtained from government agencies including the DENR, Region 10, the Department of Agriculture (DA, Region 10), and non-government organizations (notably the World Agroforestry Centre). Snowball sampling was also applied wherein nursery operators were questioned about the existence of other nurseries within the vicinity with the presumption that the nursery operators being interviewed knew other local nurseries. 
Data were gathered through personal interviews with nursery operators using a structured questionnaire. Three questionnaire versions were developed, to cover the three main nursery types based on management. Nurseries that are managed by private individuals are referred to as private nurseries, while those that are managed by a community organization or people's organization (POs) are referred to as communal nurseries and those that are managed by government agencies are referred as government nurseries. Testing and revision of questionnaires were conducted prior to interviews to ensure the questions were structured correctly and were clear enough for the respondents. Before interviews, respondents were sent letters expressing the project's interest to carry out the interview and the reasons for conducting the survey. The nursery operators' consent to the proposed interviews was obtained either through short messaging service (SMS), phone calls or personal visits. The consent of gatekeepers including the village chairmen (barangay captains) was also secured. Three teams of enumerators comprising three members each with experience in conducting surveys were formed to carry out the fieldwork. Enumerators were made aware of the survey protocols and exposed to the survey questions for familiarization before the fieldwork.

Interviews with nursery operators were carried out in 2008-09, Observations were made of the design and operation of nurseries; and global positioning system (GPS) coordinates were taken of nursery locations so that nursery coverage can be examined. The head of the household or the person in charge of the nursery was interviewed for the private category. The president of the people's organization, together with the person in charge of the nursery, answered the questions in the communal category. For government nurseries, the staff member designated to manage the nursery was interviewed. Every day after the fieldwork, the survey teams convened to discuss their activities for the day and to raise issues and constraints that could potentially hinder the survey process and thereby develop solutions to avoid experiencing a similar problem on succeeding days of the survey period.

Operators or their representatives in a total of 90 nurseries were interviewed during the survey, representing 36 private nurseries, 25 communal nurseries and 29 government-managed nurseries, covering 16 municipalities and four cities in Northern Mindanao. The data collected from the survey were organized using Microsoft Excel while partial analyses were carried out using the Statistical Package for Social Sciences (SPSS). Descriptive statistics including frequencies, percentages and means among the variables were derived to allow a comparison between the three nursery types. 


\section{RESULTS AND DISCUSSION}

\section{Characteristics of Private Nursery Operators}

Operators of private nurseries were mostly male (66.7\%). The modal age range was 45 to 54 years (38.9\%) (Table 1). More than half (55.6\%) had a family size of 4 to 6 and more than half (52.7\%) had not completed college (Table 2). The majority of private nursery operators are members of organizations (55.4\%) (Table 3). However, only $30.6 \%$ are members of agriculture and forestry-related organizations.

Table 1. Age range of nursery operators in Northern Mindanao

\begin{tabular}{lcc}
\hline Age (years) & Frequency & Relative frequency (\%) \\
\hline $25-34$ & 6 & 16.7 \\
$35-44$ & 4 & 11.1 \\
$45-54$ & 14 & 38.9 \\
$55-64$ & 5 & 13.9 \\
$65-74$ & 7 & 19.4 \\
\hline Total & 36 & 100 \\
\hline
\end{tabular}

Table 2. Educational attainment of private nursery operators in Northern Mindanao

\begin{tabular}{lcc}
\hline Educational attainment & Frequency & Relative frequency (\%) \\
\hline Not completed tertiary & & \\
education & 19 & 52.7 \\
Completed tertiary education & 16 & 44.4 \\
Postgraduate education & 1 & 2.8 \\
\hline Total & 36 & 100 \\
\hline
\end{tabular}

Table 3. Membership of organizations for Northern Mindanao private nursery operators

\begin{tabular}{lcc}
\hline Type of organization & Frequency & Relative frequency (\%) \\
\hline Not a member of any organization & 16 & 44.4 \\
Agriculture-related organization & 11 & 30.6 \\
Religious organization & 3 & 8.3 \\
School-related organization & 2 & 5.6 \\
Cooperative & 2 & 5.6 \\
Others & 2 & 5.6 \\
\hline Total & 36 & 100 \\
\hline
\end{tabular}

As indicated in Table 4, 50\% of the interviewed nursery operators reported that their nursery business is their primary source of income while $28 \%$ said being employed in private, public or non-government organizations was their main source of 
income. About $16 \%$ of nursery operators said their farms are their main source of income while the nursery business is considered as a 'sideline'. Other major sources of income were found to include retirement pension and fish vending, in which case having the nursery business is a secondary source of income. Daily average income of nursery operators based on their primary source of income ranged from 124 to 376 $\mathrm{PhP}$ per day, revealing that most of the nurseries operate on a small-scale basis. The nursery operator is usually assisted by family members. Most nursery operators relying financially on the nursery business and farming were assisted by 4 and 2 members, respectively.

Table 4. Major source of income and number of household members involved in each activity of private nursery operators in Northern Mindanao

\begin{tabular}{lcccc}
\hline $\begin{array}{l}\text { Source of } \\
\text { Income }\end{array}$ & $\begin{array}{c}\text { Frequency } \\
\mathrm{n}=36\end{array}$ & $\begin{array}{c}\text { Relative } \\
\text { frequency } \\
(\%)\end{array}$ & $\begin{array}{c}\text { Number of } \\
\text { household } \\
\text { members involved } \\
\text { in the activity }\end{array}$ & $\begin{array}{c}\text { Daily income } \\
\text { (PhP) }\end{array}$ \\
\hline Nursery & 18 & 50 & 4 & 303 \\
Employee & 10 & 28 & 1 & 376 \\
Farming & 6 & 16 & 2 & 124 \\
Pension & 1 & 3 & 1 & 300 \\
Fish vending & 1 & 3 & 1 & 200 \\
\hline
\end{tabular}

\section{Characteristics of Communal Nursery Operators}

Communal nurseries are established by a group of people living in close proximity to each other. The majority of communal nurseries (88\%) for which interviews were conducted consisted of a group of less than 100 members, the majority (54.3\%) being female.

Ages of active communal nursery members are summarized in Table 5. People in the middle age range (21 to 40 years) accounted for two-thirds of the membership, but it is notable that $32 \%$ of the active members were more than 60 years of age.

Table 5. Age range of active communal nursery members

\begin{tabular}{lcc}
\hline Age range & Number of members & Relative frequency (\%) \\
\hline Less than 20 & 13 & 0.4 \\
$21-40$ & 1152 & 39.8 \\
$41-60$ & 800 & 27.6 \\
Above 60 & 928 & 32.0 \\
\hline
\end{tabular}


Most of the communal members have a limited educational background with only $2.6 \%$ having completed a college education, and less than half having completed primary education (Table 6). These nurseries were, however, managed by the presidents of the organizations and most of them (64\%) had undergone training in nursery management.

Table 6. Educational attainment of active communal nursery members

\begin{tabular}{lcc}
\hline Educational level & Frequency & $\begin{array}{c}\text { Relative frequency } \\
(\%)\end{array}$ \\
\hline Not completed primary (elementary) & 1730 & 46.5 \\
Completed primary (elementary) & 657 & 17.6 \\
Not completed secondary (high school) & 748 & 20.1 \\
Completed secondary (high school) & 300 & 8.1 \\
Not completed tertiary (college) & 180 & 4.8 \\
Completed tertiary (college) & 96 & 2.6 \\
Postgraduate award & 10 & 0.3 \\
\hline
\end{tabular}

\section{Characteristics of Government Nursery Operators}

Government institutions managing forestry nurseries producing timber tree seedlings included various agencies of the DENR and schools, colleges and universities (SCUs). Most were managed by experienced nursery operators, foresters and agriculturists, about $90 \%$ of whom had undergone nursery-related training.

\section{Nursery Size, Capacity, Location, and Objectives}

As indicated in Table 7, nurseries with an area greater than 2 ha were only found in the private nursery category (19.4\%). The quantity of seedlings that can be accommodated in a given production time is directly related to the size of the nursery. Since most nurseries were found to have less than a 1 ha of land, it can be construed that nurseries of all three types are mostly small-scale.

Table 7. Dimensions of private, communal and government nurseries

\begin{tabular}{lcccccc}
\hline $\begin{array}{l}\text { Nursery } \\
\text { area }\end{array}$ & \multicolumn{2}{c}{ Private } & \multicolumn{2}{c}{ Communal } & \multicolumn{2}{c}{ Government } \\
\cline { 2 - 7 } (ha) & Frequency & $\begin{array}{c}\text { Rel. freq. } \\
(\%)\end{array}$ & Frequency & $\begin{array}{c}\text { Rel. freq. } \\
(\%)\end{array}$ & Frequency & $\begin{array}{c}\text { Rel. freq. } \\
(\%)\end{array}$ \\
\hline Less than 1 & 24 & 66.7 & 22 & 88 & 26 & 89.7 \\
1 to 2 & 5 & 13.9 & 0 & 0 & 3 & 10.3 \\
More than 2 & 7 & 19.4 & 0 & 0 & 0 & 0 \\
No answer & 0 & 0 & 3 & 12 & 0 & 0 \\
\hline Total & 36 & 100 & 25 & 100 & 25 & 100 \\
\hline
\end{tabular}

\section{Seedling Production Capacity}

Table 8 indicates that most nurseries in the region produced less than 50,000 seedlings annually. Government nurseries, produced more seedlings than private and 
communal nurseries, with $20 \%$ of them producing more than 50,000 seedlings per annum.

Table 8. Number of seedlings produced annually by the three nursery types ${ }^{\mathrm{a}}$

\begin{tabular}{|c|c|c|c|c|c|c|}
\hline \multirow{2}{*}{$\begin{array}{l}\text { Annual } \\
\text { number of } \\
\text { seedlings } \\
\text { produced }\end{array}$} & \multicolumn{2}{|c|}{ Private } & \multicolumn{2}{|c|}{ Communal } & \multicolumn{2}{|c|}{ Government } \\
\hline & Frequency & $\begin{array}{c}\text { Relative } \\
\text { frequency } \\
(\%)\end{array}$ & Frequency & $\begin{array}{c}\text { Relative } \\
\text { frequency } \\
(\%)\end{array}$ & Frequency & $\begin{array}{c}\text { Relative } \\
\text { frequency } \\
(\%)\end{array}$ \\
\hline $\begin{array}{l}\text { Cannot } \\
\text { estimate }\end{array}$ & 0 & 0 & 2 & 8 & 1 & 3.4 \\
\hline $\begin{array}{l}<12,500 \\
12,501-\end{array}$ & 20 & 55.6 & 16 & 64 & 12 & 41.4 \\
\hline $\begin{array}{l}25,000 \\
25,001-\end{array}$ & 3 & 8.3 & 3 & 12 & 4 & 13.8 \\
\hline $\begin{array}{l}37,500 \\
37,501-\end{array}$ & 5 & 13.9 & 0 & 0 & 2 & 6.9 \\
\hline $\begin{array}{c}50,000 \\
>\end{array}$ & 3 & 8.3 & 1 & 4 & 4 & 13.8 \\
\hline 50,000 & 5 & 13.9 & 3 & 12 & 6 & 20.7 \\
\hline Total & 36 & 100 & 25 & 100 & 29 & 100 \\
\hline
\end{tabular}

${ }^{a}$ Nurseries producing more than 50,000 seedlings annually are not considered smallholder nurseries (Tolentino et al. 2003).

The low seedling supply in the region can be attributed to the low production of the three nursery types. However, these nurseries have the potential to produce much higher numbers of seedlings given a strong demand. Nursery operators consistently claim that demand is low despite the annual log production deficit of $493,591 \mathrm{~m}^{3}$ in the region. Intensification of reforestation efforts to combat this deficit could increase seedling demand.

\section{Nursery Location}

Most private and government nurseries (77.8\% and $75.9 \%$ respectively) are situated near the main road, with distances ranging from 1 to $625 \mathrm{~m}$ (Table 9). In contrast, most of the communal tree nurseries (62\%) are situated more than $625 \mathrm{~m}$ away from the main road, which limits the accessibility of buyers. Closeness to the main road is essential as a form of advertising to attract commuters to purchase seedlings. Also, hauling cost is directly related to proximity to the main road meaning nurseries farthest away from main roads incur the highest cost in hauling seedlings, making the seedling cost relatively high and less attractive to buyers. 
Table 9. Proximity of nurseries in Region 10 to the main road

\begin{tabular}{lcccccc}
\hline $\begin{array}{l}\text { Distance from } \\
\text { a main } \\
\text { road (m) }\end{array}$ & \begin{tabular}{c} 
Relative \\
frequency \\
\cline { 2 - 7 }
\end{tabular} & $\begin{array}{c}\text { Private } \\
\text { Frequency }\end{array}$ & $\begin{array}{c}\text { Requency } \\
\text { Frequency } \\
(\%)\end{array}$ & $\begin{array}{c}\text { Government } \\
\text { Frequency }\end{array}$ & $\begin{array}{c}\text { Relative } \\
\text { frequency } \\
(\%)\end{array}$ \\
\hline $1-625$ & 28 & 77.8 & 9 & 36.0 & 22 & 75.9 \\
$626-1251$ & 2 & 5.6 & 2 & 8.0 & 4 & 13.8 \\
$1252-1877$ & 3 & 8.3 & 1 & 4 & 1 & 3.4 \\
$2504-3129$ & 1 & 2.8 & 0 & 0 & 0 & 0 \\
$4382-5007$ & 2 & 5.6 & 2 & 8 & 0 & 0 \\
$5634-6259$ & 0 & 0 & 1 & 4 & 0 & 0 \\
$6886-7511$ & 0 & 0 & 1 & 4 & 0 & 0 \\
$11,894-12,519$ & 0 & 0 & 3 & 12 & 0 & 0 \\
$12,520-13,145$ & 0 & 0 & 1 & 4 & 0 & 0 \\
$15,650-16,275$ & 0 & 0 & 2 & 8 & 0 & 0 \\
$1875-2503$ & 0 & 0 & 0 & 0 & 1 & 3.4 \\
$2504-3129$ & 0 & 0 & 0 & 0 & 1 & 3.4 \\
$24,414-25,039$ & 0 & 0 & 2 & 0 & 0 & 0 \\
No answer & 0 & 0 & 1 & 4 & 0 & 0 \\
\hline Total & 36 & 100 & 25 & 100 & 29 & 100 \\
\hline
\end{tabular}

\section{Objectives of Production}

As indicated in Table 10, private nurseries are business-oriented with $41.7 \%$ of them raising seedlings both for sale and for own use, and 30.6\% raising seedlings solely for sale. A number of private nurseries (19.4\%) also raise seedlings for sale, personal use and for free distribution.

Table 10. Main purposes of nursery operation

\begin{tabular}{|c|c|c|c|c|c|c|}
\hline \multirow[t]{2}{*}{ Purpose } & \multicolumn{2}{|c|}{$\begin{array}{c}\text { Private } \\
\text { nurseries }\end{array}$} & \multicolumn{2}{|c|}{$\begin{array}{c}\text { Communal } \\
\text { nurseries }\end{array}$} & \multicolumn{2}{|c|}{$\begin{array}{l}\text { Government } \\
\text { nurseries }\end{array}$} \\
\hline & Frequency & $\begin{array}{r}\text { Rel. } \\
\text { freq. } \\
(\%)\end{array}$ & Frequency & $\begin{array}{r}\text { Rel. } \\
\text { freq. } \\
(\%)\end{array}$ & Frequency & $\begin{array}{l}\text { Rel. } \\
\text { freq. } \\
(\%)\end{array}$ \\
\hline For sale & 11 & 30.6 & 3 & 12 & 2 & 6.9 \\
\hline For personal use $\mathrm{a}^{\mathrm{a}} /$ internal use $^{\mathrm{b}}$ & 2 & 5.6 & 0 & 0 & 0 & 0 \\
\hline For free distribution & 0 & 0 & 22 & 88 & 10 & 34.5 \\
\hline For sale and personal ${ }^{\mathrm{a}} /$ agency use $\mathrm{b}^{\mathrm{b}}$ & 15 & 41.7 & 0 & 0 & 0 & 0 \\
\hline $\begin{array}{l}\text { For personal }{ }^{\mathrm{a}} / \text { agency use }{ }^{\mathrm{b}} \text { and free } \\
\text { distribution }\end{array}$ & 1 & 2.8 & 0 & 0 & 10 & 34.5 \\
\hline For sale and free distribution & 0 & 0 & 0 & 0 & 5 & 17.2 \\
\hline $\begin{array}{l}\text { For sale, personal use }{ }^{\mathrm{a}} / \text { agency use }^{\mathrm{b}} \\
\text { and free distribution }\end{array}$ & 7 & 19.4 & 0 & 0 & 2 & 6.9 \\
\hline Total & 36 & 100 & 25 & 100 & 29 & 100 \\
\hline
\end{tabular}

${ }^{\mathrm{a}}$ Private nurseries; ${ }^{\mathrm{b}}$ Government nurseries 
Most of the communal nurseries (88\%) produce planting materials for free distribution to their members, while only a few are engaged in selling seedlings. Of the government nurseries, $34.5 \%$ raise seedlings for two reasons - sale and agency use - while the same percentage are producing seedling for sale and free distribution.

\section{Sustainability of nursery operation}

The majority of private, communal and government nurseries in northern Mindanao have been operating on a continuous basis. However, a lack of funds is common among the three types of nurseries resulting in an 'on and off' mode of operation, as shown in Table 11. Private nurseries have less difficulty maintaining operation than other nurseries and $94 \%$ have been operating continuously since the beginning of the nursery operation (Table 12).

Table 11. Reasons for intermittent operation of private, communal and government nurseries

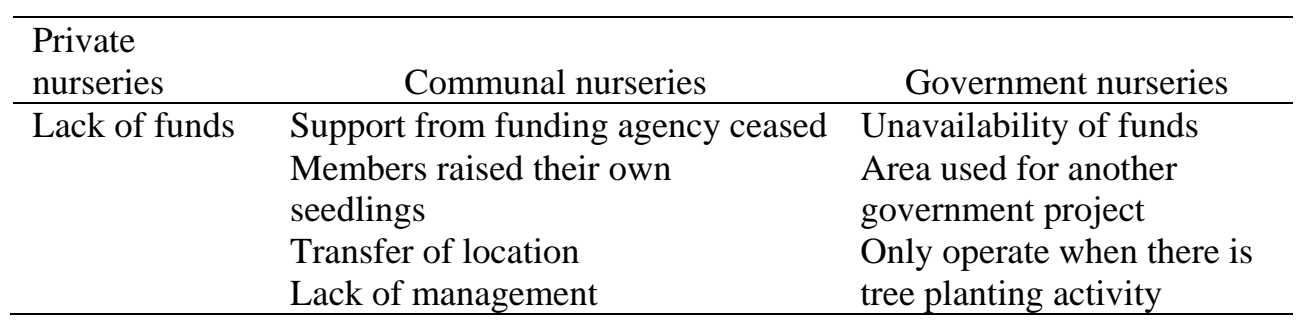

Table12. Consistency in operation of private, communal and government nurseries since opening

\begin{tabular}{|c|c|c|c|c|c|c|}
\hline \multirow{2}{*}{$\begin{array}{l}\text { Nursery } \\
\text { Operation }\end{array}$} & \multicolumn{2}{|c|}{ Private nurseries } & \multicolumn{2}{|c|}{ Communal nurseries } & \multicolumn{2}{|c|}{ Government nurseries } \\
\hline & Frequency & $\begin{array}{c}\text { Rel. freq. } \\
(\%)\end{array}$ & Frequency & $\begin{array}{c}\text { Rel. freq. } \\
(\%)\end{array}$ & Frequency & $\begin{array}{c}\text { Rel. freq. } \\
(\%)\end{array}$ \\
\hline Cor & 34 & 94.4 & 16 & 64.0 & 26 & 89.7 \\
\hline Intermi & 2 & 5.6 & 9 & 36.0 & 3 & 10.3 \\
\hline Total & 36 & 100.0 & 25 & 100.0 & 29 & 100.0 \\
\hline
\end{tabular}

Communal nurseries are the most affected by the unavailability of funds and in most cases, when funding from support organizations ceases, those nurseries most heavily reliant on this support fail to continue their operation. Other reasons such as that the members have already started to grow the seedlings they need themselves, failure of group cooperation and the transfer of the nursery to another location were 
mentioned as reasons for the intermittent operation of communal nurseries. Government nurseries reasoned that their intermittent operation, aside from unavailability of funds, is due to conflict in land use and the fact that the nursery only operates when a scheduled tree planting activity is taking place. Government nurseries, as in the case of private nurseries, experienced only a few cases of interruption with their operation. This is the result of a stable funding support from the government for these government nurseries.

\section{CONCLUSION}

The three nursery types in Northern Mindanao - private, community and government nurseries - differ in management type as well as in other aspects such as personal characteristics of managers, seedling production capacity, access to financial support and continuity of operation. Private nurseries are usually managed by a single individual with the help of household members. In some instances, in the case of wellestablished nurseries, licensed professionals in forestry and agriculture are responsible for the management of the nursery. Private nurseries are stable considering the large number of private nurseries that have operated continuously since initial establishment.

Communal nurseries are managed by the organization's president, who usually has attended training but in most cases had been unable to finish formal education. Government nurseries are mostly staffed by trained individuals, and in some cases are overseen by licensed professionals in agriculture and forestry.

Private nurseries are mostly established for commercial purposes hence part of their profit can be allocated to finance future nursery operations. Government nurseries receive financial support from the government for free distribution of seedlings, and also generate income from some sales of seedlings. On the other hand, communal nurseries produce seedlings mainly for free distribution to their members utilizing funds obtained from support organizations. In most cases where support ceases the nursery operation also fails, thus making the nursery endeavour unsustainable.

The low seedling availability in Northern Mindanao may be attributed to the smallscale production of nearly all nurseries. However, production is dictated by demand, and therefore measures to increase demand will also lead to an increase in seedling production activities.

\section{POLICY IMPLICATIONS}

The constraints on the forestry nursery sectors in Northern Mindanao can be augmented through the adoption of an accreditation scheme for nurseries with the support of DENR, similar to the scheme that exists for the fruit tree nursery sector. This scheme may regulate seedling quality, thus minimizing, if not eliminating, the supply of inferior seedlings in the market. On the other hand, the government nursery sectors' practice of supplementing their own seedling production by acquiring lowpriced seedlings - which undermines quality - should be ceased and replaced by the 
purchase of high quality planting materials. Moreover, the use of high quality seedlings must be incorporated in government programs such as the National Forestation Program and Green Philippines Program. Locally, capacity building of nursery operators may be undertaken through training in high quality seedling production technologies. At the same time, the mindset of the buyers should be changed through an intensive information campaign to increase their demand for high quality seedlings. Such a demand-driven initiative will in turn lead to the production of high quality seedlings by the nursery operators. Improved organisation of tree nurseries in Northern Mindanao is also important to facilitate the transfer of high quality seedling technology from researchers to nursery operators. This will also provide an avenue for discussion on improving seedling quality and the tree nursery sector as a whole.

\section{REFERENCES}

BERTOMEU, M. 2003. Growing Agroforestry Trees: Farmers' Experiences with Individual and Group Nurseries in Claveria, the Philippines. International Centre for Research in Agroforestry, SEA Regional Research Programme. Claveria, World Agroforestry Centre (ICRAF), Claveria. Accessed on 20 May 2009. Available at http://www.worldagroforestry.org/sea/ph/02_pubs.htm and http://www.worldagroforestrycentre.org/ Sea/Publications.

DART, P.J., BROWN, S.M, SIMPSON, J.A., HARRISON, S.R. and T.J. VENN. 2001. Experiences from ACIAR trials of the suitability and performance of Australian tree species. In: S.R. Harrison and J.L. Herbohn, Socio Economics of Adoption of Australian Tree Species in the Philippines. ACIAR Monograph 75. Canberra. 192 pp.

GALINATO, C.B. 2009. Status of tree farming in Northern Mindanao. Paper presented on 24 Febuary 2009 at a workshop on Developing Mechanisms for Accrediting Tree Nurseries held in Cagayan de Oro, the Philippines.

HARRISON, S.R. and J.L. HERBOHN. 2001. Socio Economics of Adoption of Australian Tree Species in the Philippines. Canberra. ACIAR Monograph 75.

LONGMAN, K. 2002. Tropical Trees: a Practical Manual for Growing Good Nursery Stock. Blaketon Hall Ltd, Exeter, United Kingdom.

MERCADO, A. and C. PIÑON. 2008. Tree seedling production systems in Northern Mindanao, the Philippines. Small-scale Forestry: Special Issue on Seedling Production Systems.7(3-4): 225-243.

NSO (NATIONAL STATISTICS OFFICE). 2007. Region 10 - Northern Mindanao, the Philippines. Accessed on 20 March 2009. Available at http://www.census.gov.ph/data/quickstat/qs100812.html.

TOLENTINO, E. Jr, CARANDANG, W. and J. ROSHETKO. 2003. Evaluation of Smallholder Tree Farmer's Nursery: Quality Stock Production in Support of the Tree Domestication Program of the Philippines. ICRAF-Philippines, Laguna. 